\title{
Estimation of Nitrogen Transformation in Cau River Basin, Vietnam Using a Material Flow Analysis Model
}

\section{Chinh, Le Van}

Laboratory of Water Environment Engineering, Division of Bioproduction Environmental Sciences, Department of Agro-environmental Sciences, Faculty of Agriculture, Kyushu University I

Department of Social and Natural Sciences, Ministry of Science and Technology of Vietnam

\section{Hi ramatsu, Kazuaki}

Laboratory of Water Environment Engineering, Division of Bioproduction Environmental Sciences, Department of Agro-environmental Sciences, Faculty of Agriculture, Kyushu University

Harada, Masayoshi

Laboratory of Water Environment Engineering, Division of Bioproduction Environmental Sciences, Department of Agro-environmental Sciences, Faculty of Agriculture, Kyushu University

Thao, Ta Thi

Laboratory of Water Environment Engineering, Division of Bioproduction Environmental Sciences, Department of Agro-environmental Sciences, Faculty of Agriculture, Kyushu University | University of Science, Vietnam National University

他

https://doi.org/10.5109/1801776

出版情報：九州大学大学院農学研究院紀要. 62 (1)，pp. 153-162，2017-02-24. Faculty of Agriculture, Kyushu University

バージョン :

権利関係 : 


\title{
Estimation of Nitrogen Transformation in Cau River Basin, Vietnam Using a Material Flow Analysis Model
}

\section{Le Van CHINH ${ }^{1 *}$, Kazuaki HIRAMATSU, Masayoshi HARADA, Ta Thi THAO ${ }^{2}$, Le Phu DONG ${ }^{2}$, Nguyen Trong $\mathrm{CUU}^{3}$ and Truong Thi LAN ${ }^{3}$}

\author{
Laboratory of Water Environment Engineering, Division of Bioproduction Environmental Sciences, \\ Department of Agro-environmental Sciences, Faculty of Agriculture, \\ Kyushu University, Fukuoka 812-8581, Japan \\ (Received October 3, 2016 and accepted November 4, 2016)
}

\begin{abstract}
Excess nitrogen causes harmful algal blooms and pollution of surface water and groundwater, and has become an increasingly urgent issue in Cau River Basin, Vietnam. However, due to a lack of information, researchers struggle to find suitable tools for analysis of the problem. In order to overcome this, we introduce a material flow analysis (MFA) model to assess the environmental impact of human activities on nutrient flows at the river basin scale. The MFA model was used to estimate nitrogen transformation and identify the main source of nitrogen in Hai Duong province in Cau River Basin. The dynamic transformation of nitrogen was quantified using results from a survey and previous studies. All nitrogen inputs such as from agriculture, aquaculture, and domestic sources, as well as nitrogen outputs including to the atmosphere, surface water, and soil and groundwater were considered and estimated by mass balance and network equations. The rate of nitrogen transformation in each process and parameters of the MFA model were then determined and verified by measured data. The MFA model results indicate that nitrogen loads to the air accounted for $64.2 \%$ whereas nitrogen loads to surface water and soil or groundwater accounted for $23.9 \%$ and $11.9 \%$ respectively. Nitrogen loads from rice paddies were the main contributors to surface water $(55.7 \%)$. Other contributions to surface water were from aquaculture $(20.6 \%)$ and waste water $(23.7 \%)$. Using the defined parameters and input data, nitrogen loads in Hai Duong province were estimated for a scenario in 2020. The MFA model is a useful tool that will support managers and authorities in assessing the economic development plan of Hai Duong province. It will also provide researchers with useful input data and information for dealing with environmental issues in Cau River Basin.
\end{abstract}

Key words: surface water, groundwater, mass balance, nitrogen load, transfer coefficient

\section{INTRODUCTION}

Selection of computational tools for estimating and simulating the flow and environmental factors of river basins in the absence of observed data is challenging. Alternatives must be selected based on available data (Chinh et al., 2015a). However, computation results must also be robust enough to meet the requirements of assessments (Chinh et al., 2015b). A material flow analysis (MFA) is a useful tool for environmental assessment. Brunner and Rechberger (2004) defined MFA as a systematic assessment of the flows and stocks of materials within a system delineated in space and time. It connects the sources, pathways, and intermediate and final sinks of a material. MFA is considered an attractive tool for environmental planning through the analysis of various pollutants. The first national-level material flow accounts were presented in the early 1990s for Austria (Steurer, 1992) and Japan (Japan Environment Agency, 1992). Since then, MFA has become a rapidly growing field of scientific interest and major efforts have been undertaken to harmonize the different methodological

\footnotetext{
Department of Social and Natural Sciences, Ministry of Science and Technology of Vietnam

2 University of Science, Vietnam National University

3 Vietnam Environment Administration, Ministry of Natural Resources and Environment of Vietnam

* Corresponding author (E-mail: chinhhec1@yahoo.com)
}

approaches developed. Recently, MFA has been applied by several researchers to nutrients (e.g., Belevi et al., 2000; Sinsupan, 2004; Montangero, 2006; Montangero and Belevi, 2007).

One of the main purposes of MFA is to develop simple and reliable models of reality. In most cases, systems comprising more than 15 processes are unnecessarily complex and difficult to handle (Brunner and Rechberger, 2004). Processes and goods are selected according to their relevance to the study objectives. MFA has been applied in many areas, for instance to assess production quality and to quantify nutrient loads from industrial processing or the production cycle. Many researchers have applied MFA to environmental areas. For example, Belevi et al. (2000) used MFA to aid creation of a water and solid waste management plan in Kumasi, Ghana. Results indicated that nitrogen and phosphorus loads were mainly from households, rather than from waste water from cities, suburbia, industry, or solid or waste treatment factories. Consequently, they proposed an alternative for household water and solid waste management in order to reduce nitrogen and phosphorus loads by $30 \%$. Montangero et al. (2004) estimated nitrogen loads in Viet Tri City, Vietnam using MFA. They successfully simulated dynamic nitrogen transportation and found effective and economic alternatives to improve the environment in Viet Tri. Substance selection depends on project scope and objectives. Usually, indicator substances are selected e.g., phosphorus or nitrogen in nutrient-focused 
research; heavy metals like $\mathrm{Pb}, \mathrm{Cd}, \mathrm{Cu}$, or $\mathrm{Zn}$ as indicators for industrial activity; and carbon for biomass flux (Brunner and Rechberger, 2004).

Excess nitrogen, which causes harmful algal blooms and pollution of surface water and groundwater, has become an increasingly urgent issue in Cau River Basin, Vietnam. Therefore, in this study, the MFA model was applied to provide an overview of existing nitrogen flows, in order to identify weaknesses in nutrient management in Hai Duong province in the Cau River Basin of Vietnam.

\section{MATERIALS AND METHODS}

\section{Study area}

Hai Duong province, located in the downstream of Cau River, Vietnam, has a total area of 165599 ha and is surrounded by Bac Ninh, Bac Giang, Quang Ninh, Hai Phong, Thai Binh, and Hung Yen provinces (Fig. 1). The river network is dense, and includes the Bac Hung Hai irrigation system, which was built in 1958 and contains canal systems, dams, and pumping stations in order to irrigate and drain water for Hung Yen, Hai Duong, and Bac Ninh provinces and part of Hanoi city. In 2012, the total agricultural area of Hai Duong province was about 106577 ha, of which paddy fields occupy 63205 ha (59.3\%).

Surface water in Hai Duong province is abundant, supplied from Cau River, Bac Hung Hai system, and reservoirs. However, water quantity and quality is negatively impacted by nature and human activities. Surface water has become increasingly polluted due to several factors:

(1) In order to increase production yield, farmers apply excessive fertilizer and pesticides, causing pollution of surface water by toxic organic and inorganic matter; (2) Sewage from residential areas such as Hai Duong

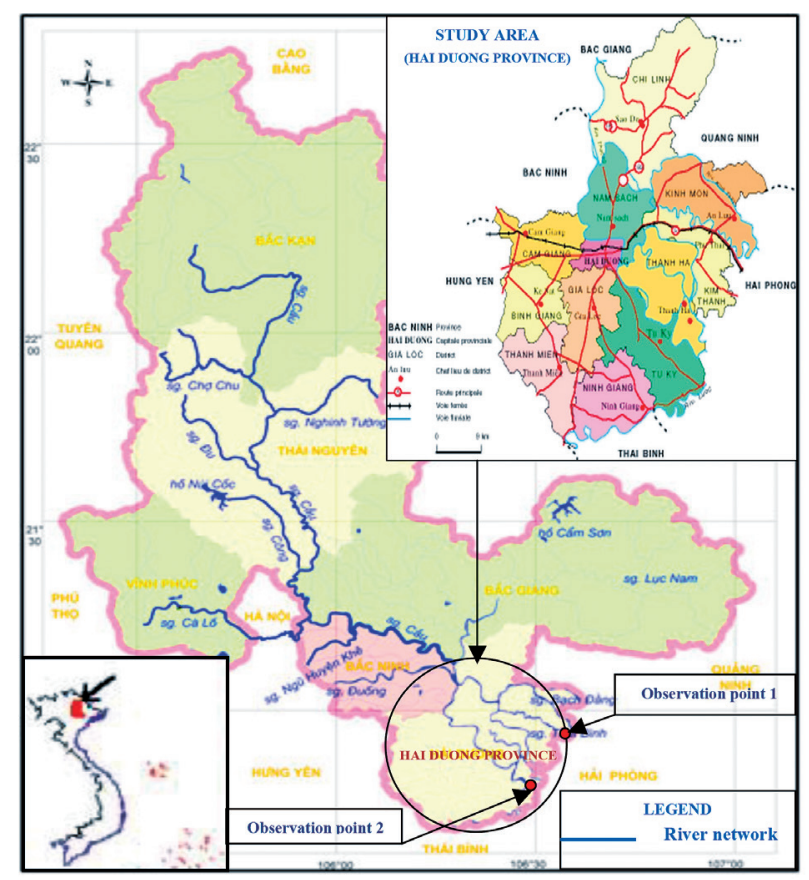

Fig. 1. Location of Cau River basin and study area. city and towns is not treated but discharged directly into the rivers and reservoir; (3) Waste water flows from industrial areas and factories are not adequately treated. According to several indicators the water system is polluted, which affects surface water downstream in Cau River Basin. (4) Waste water flows from hospitals and clinics are inadequately treated, causing serious pollution in the form of toxic chemicals and bacteria that impacts communities; (5) Rivers are also polluted by oil, fuel, and other waste from navigation activities; (6) In the rainy season, rivers are polluted by surface flows, containing many kinds of minerals, bacteria, suspended solids, organic and inorganic matter; (7) In addition, waste water from livestock and aquaculture is not treated but flows directly into the canal systems and rivers.

Surface water plays an important role in the socioeconomic development of Hai Duong Province, because it provides water for industrial and agricultural activities and domestic use. Therefore, the quantity and quality of surface water are evaluated annually in order to meet the requirements of planning and orientation as well as environmental protection. However, the water quality of Bac Hung Hai irrigation system and Cau River Basin has degraded gradually and nitrogen concentration has increased. Therefore, in order to find alternative means of reducing pollution in the study area, the main source of the nitrogen load must be determined.

\section{Materials}

Monthly discharge of surface water and concentration of total nitrogen $\left(\mathrm{NO}_{2}{ }^{-}-\mathrm{N}, \mathrm{NO}_{3}{ }^{-} \mathrm{N}, \mathrm{NH} 4^{+}-\mathrm{N}\right)$ were measured at two outlets, which included surface water from the study area and discharge to downstream of Cau River from September 2011 to March 2013 (Fig. 1). Samples were analysed by the Hai Duong Center for Environmental Monitoring and Analysis. The monthly discharge of waste water and concentration of total nitrogen were at the same time also collected from the main industrial zone located in the center of Hai Duong province. Other necessary input data such as concentration of total nitrogen in supply and rain water, population size, and amount of fish and liverstock products were collected from statistical data. These data were used to verify the parameters of the MFA model. Since the input data, which were collected in 2012, are more synchronous

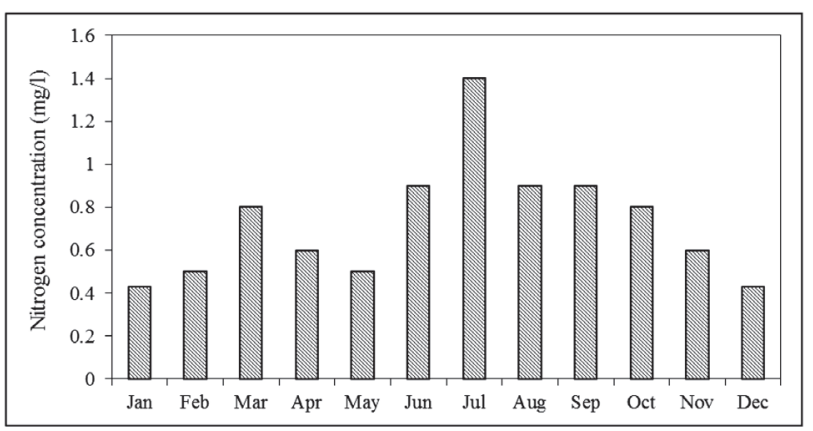

Fig. 2. Measured concentration of total nitrogen at outlet No. 1 in 2012. 


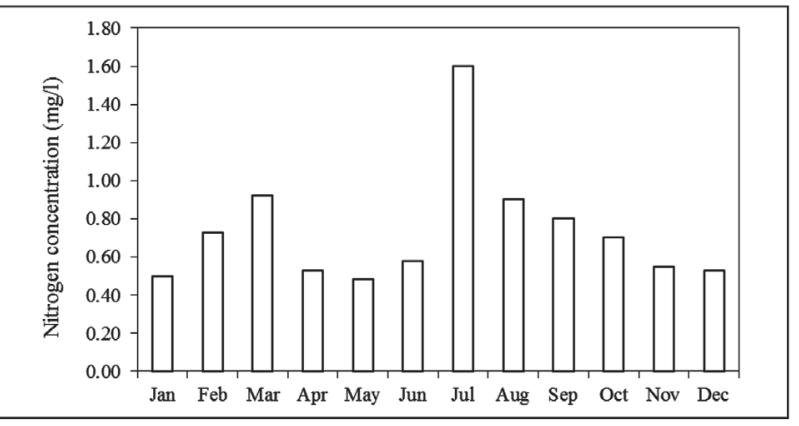

Fig. 3. Measured concentration of total nitrogen at outlet No. 2 in 2012.

than those from 2011 and 2013, the input and measured data in 2012 were selected for paramter verification and to evaluate the accuracy of the MFA model. The measured concentration of total nitrogen at the two outlets is depicted in Figs. 2 and 3.

\section{Methodology}

MFA is based on two scientific approaches: systematic and mass balance. This method can be applied across many sectors, especially for identification of pollutant sources by analyzing pollutant flow, as well as the transformation of environmental and human actives. On this basis, it is possible to accurately assess the main pollutant sources and to give the most suitable alternatives for plans and environmental management. The flowchart of the MFA model for Hai Duong province, Cau River Basin is described in Fig. 4.

Information on mass flows can either be taken from databases (e.g., bureaus of statistics, industrial associa-

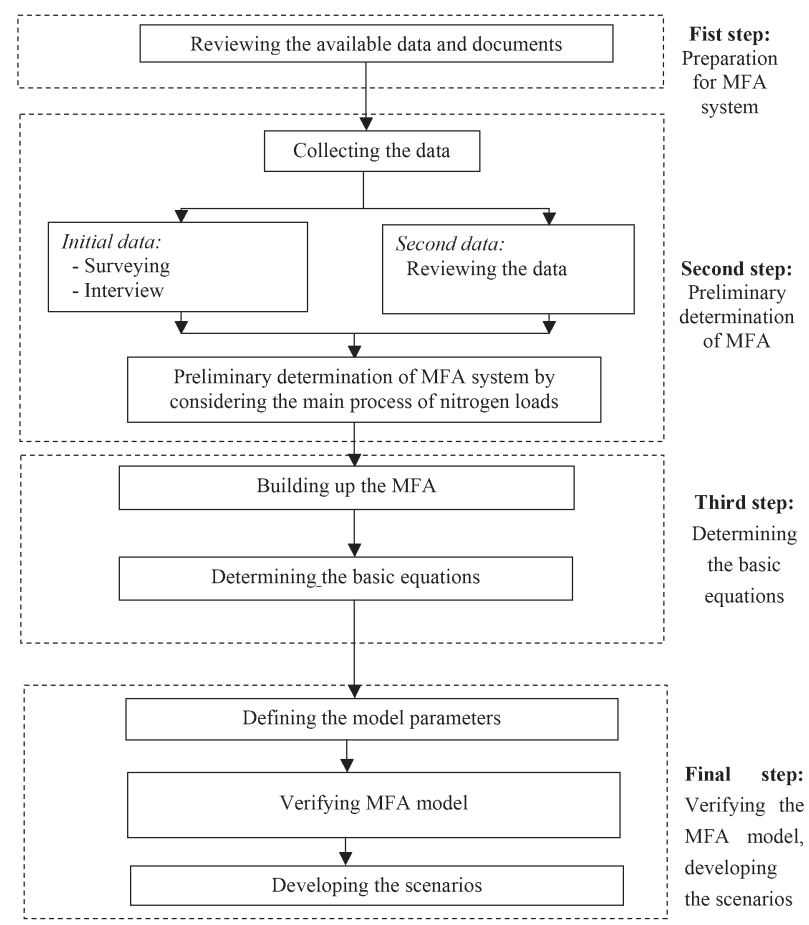

Fig. 4. Plan for studying the material flow analysis (MFA) of nitrogen transformation in Hai Duong province. tions, national or international environmental protection agencies, literature) or measured on-site (directly or indirectly). Sampling plans should be elaborated to produce rigorous and reproducible results. Material flows can also be assessed based on assumptions and crosscomparisons between similar systems. The reliability of data must be carefully considered. The collection, evaluation, and handling of data are core tasks in MFA (Brunner and Rechberger, 2004). There are four steps in constructing the MFA model as given below.

Preparation for MFA system delineation (step 1):

All nitrogen processes were initially reviewed including: (1) household; (2) on-site toilets; (3) water drainage; (4) solid waste collection; (5) water supply; (6) markets; (7) golf courses; (8) forests; (9) parks; (10) industry; (11) waste dumps; (12) livestock; (13) aquaculture; (14) cultivation; (15) surface water; (16) groundwater; and (17) atmosphere. However, according to the available data, there are no forests and golf courses in the study area, and the area of parks is insignificant.

\section{Preliminary determination of MFA (step 2):}

A preliminary MFA on nitrogen transformation in Hai Duong province was established (Fig. 5) based on information from the literature, available data, and the main environmental issues. Three potential sources of nitrogen (golf courses, forests, and parks) were not considered since their contribution of nitrogen is negligible (Table 1).

Table 1. Processes considered in general, preliminary, and final material flow analysis (MFA) systems

\begin{tabular}{|c|c|c|c|c|}
\hline $\mathrm{TT}$ & Name of process & $\begin{array}{l}\text { General } \\
\text { MFA } \\
\text { system }\end{array}$ & $\begin{array}{c}\text { Preliminary } \\
\text { MFA } \\
\text { system }\end{array}$ & $\begin{array}{c}\text { Final } \\
\text { MFA } \\
\text { system }\end{array}$ \\
\hline 1 & Household & $\sqrt{ }$ & $\sqrt{ }$ & $\sqrt{ }$ \\
\hline 2 & Onsite toilette & $\sqrt{ }$ & $\sqrt{ }$ & $\sqrt{ }$ \\
\hline 3 & Water drainage & $\sqrt{ }$ & $\sqrt{ }$ & $\sqrt{ }$ \\
\hline 4 & Solid waste collection & $\sqrt{ }$ & $\sqrt{ }$ & $\sqrt{ }$ \\
\hline 5 & Supply water & $\sqrt{ }$ & $\sqrt{ }$ & Neglectable \\
\hline 6 & Market & $\sqrt{ }$ & $\sqrt{ }$ & $\sqrt{ }$ \\
\hline 7 & Golf courses & $\sqrt{ }$ & Neglectable & Neglectable \\
\hline 8 & Forest & $\sqrt{ }$ & Neglectable & Neglectable \\
\hline 9 & Parks & $\sqrt{ }$ & Neglectable & Neglectable \\
\hline 10 & Industry & $\sqrt{ }$ & $\sqrt{ }$ & Neglectable \\
\hline 11 & Waste dump & $\sqrt{ }$ & $\sqrt{ }$ & $\sqrt{ }$ \\
\hline 12 & Livestock & $\sqrt{ }$ & $\sqrt{ }$ & $\sqrt{ }$ \\
\hline 13 & Aquaculture & $\sqrt{ }$ & $\sqrt{ }$ & $\sqrt{ }$ \\
\hline 14 & Cultivation & $\sqrt{ }$ & $\sqrt{ }$ & $\sqrt{ }$ \\
\hline 15 & Surface water & $\sqrt{ }$ & $\sqrt{ }$ & $\sqrt{ }$ \\
\hline 16 & Groundwater & $\sqrt{ }$ & $\sqrt{ }$ & $\sqrt{ }$ \\
\hline 17 & Atmosphere & $\sqrt{ }$ & $\sqrt{ }$ & $\sqrt{ }$ \\
\hline
\end{tabular}

Note: $(\sqrt{ })$ applicable process in MFA system 


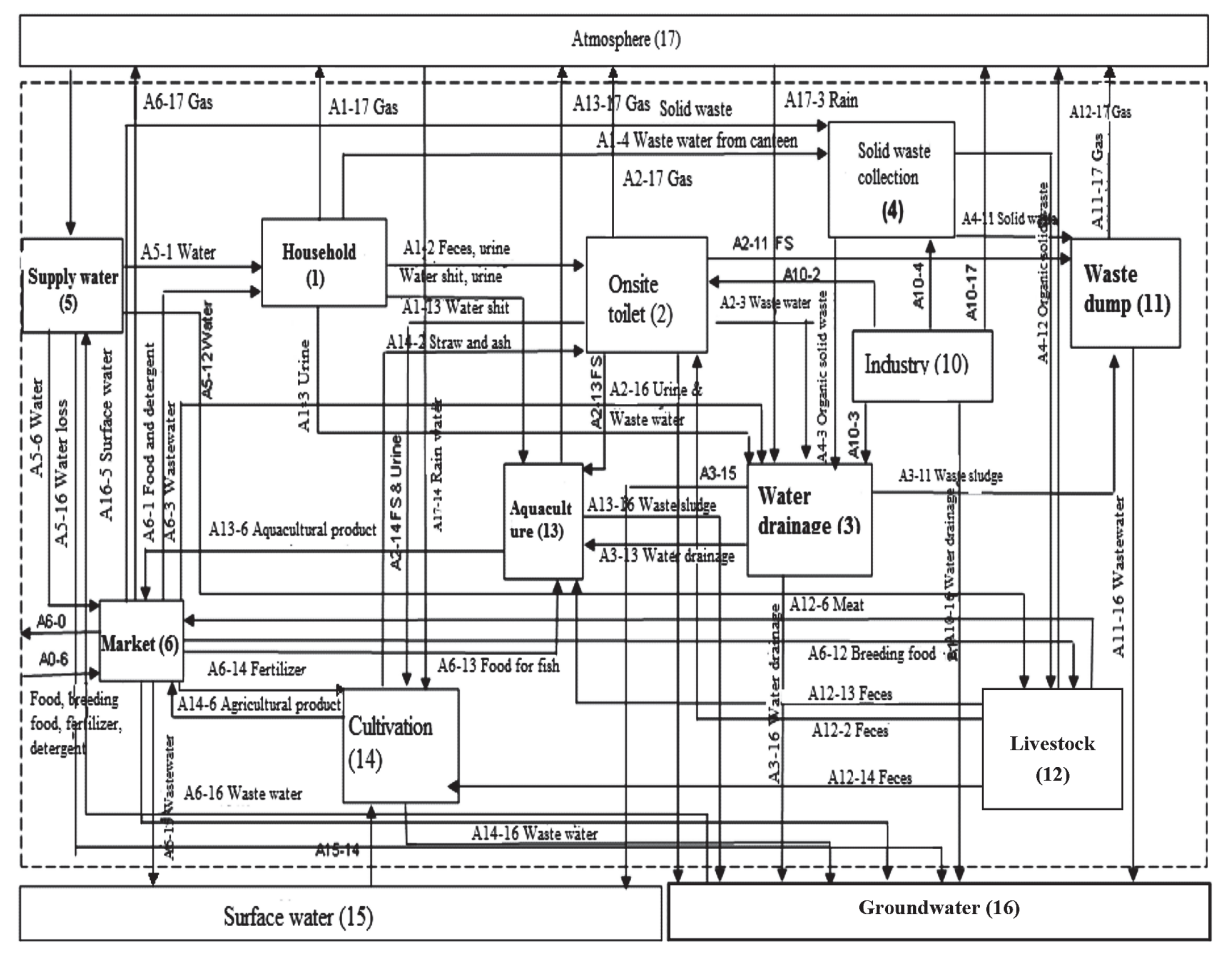

Fig. 5. Preliminary material flow analysis (MFA) of nitrogen transformation in Hai Duong province.

\section{Determining the basic equations (step 3):}

The MFA system was evaluated and established after surveys. The MFA model was developed in Microsoft Excel. There are two basic equations: mass balance and network. The mass balance equations of each specific process within the boundary of the MFA system were constructed based on the law of conservation of matter as follows:

$$
\frac{d M_{(i)}}{d t}=A_{(i) \text { in }}-A_{(i), \text { out }}
$$

Equation 1 shows that the change in nitrogen of each process $i$ is equal to the difference between its total input and output discharge $\left(A_{(i) \text {,in }}\right.$ and $A_{(i) \text {,out }}$ are total nitrogen input and output respectively). The most important mass balance equations estimate the total nitrogen that remains in each process and discharges into the air, surface water, and groundwater.

The MFA network equations are constructed based on expert knowledge through transfer coefficients, which are model parameters that describe the partitioning of a substance in a process and are defined for each output good of a process. The transfer coefficient gives the percentage of the total throughput of nitrogen that is transferred into a specific output good. It is a substance-specific value. Furthermore, transfer coefficients are technology-specific values dependent on process characteristics, and are not necessarily constant. They can depend on many variables such as process conditions (e.g., temperature, pressure) as well as input composition. Some transfer coefficients can be regarded as constant within a certain range, which makes them useful for sensitivity and scenario analyses (Brunner and Rechberger, 2004). The transfer coefficients $\alpha$ of nitrogen in a specific flow $j$ from process $i$ are equal to the ratio of output amounts $A_{\text {out }}$ to total nitrogen flow entering $\sum A_{\text {in }}$ as presented in Equation 2.

$$
\alpha_{(i, j)}=\frac{A_{(i, j), \text { out }}}{\sum A_{(i), \text { in }}}
$$

\section{Verifying parameters and MFA model (Step 4):}

The nitrogen transfer coefficients depend on many variables such as process conditions as well as input composition. For example, the nitrogen transfer coefficient from the cultivation process into surface water depends on variables including weather conditions and cropping seasons, and input composition including amount and dissolution rate of fertilizer, cropping patterns, and crop areas as a percentage of the total cultivation area. Transfer coefficients play an important role in an MFA system, as they connect the nitrogen flow between each process.

Based on Equations 1 and 2, the MFA system in Hai Duong province in 2012 was simulated. Model parameters were verified using the following steps. (1) A random value was defined for each variable, which affected model parameters according to a probability distribution; (2) Values of parameters we calculated based on the random variables, input composition, and network equations; (3) Steps 1 and 2 were repeated until acceptable mean errors of all parameters were obtained. The most important consideration is the minimization of the number of input data and network equations. Therefore, 


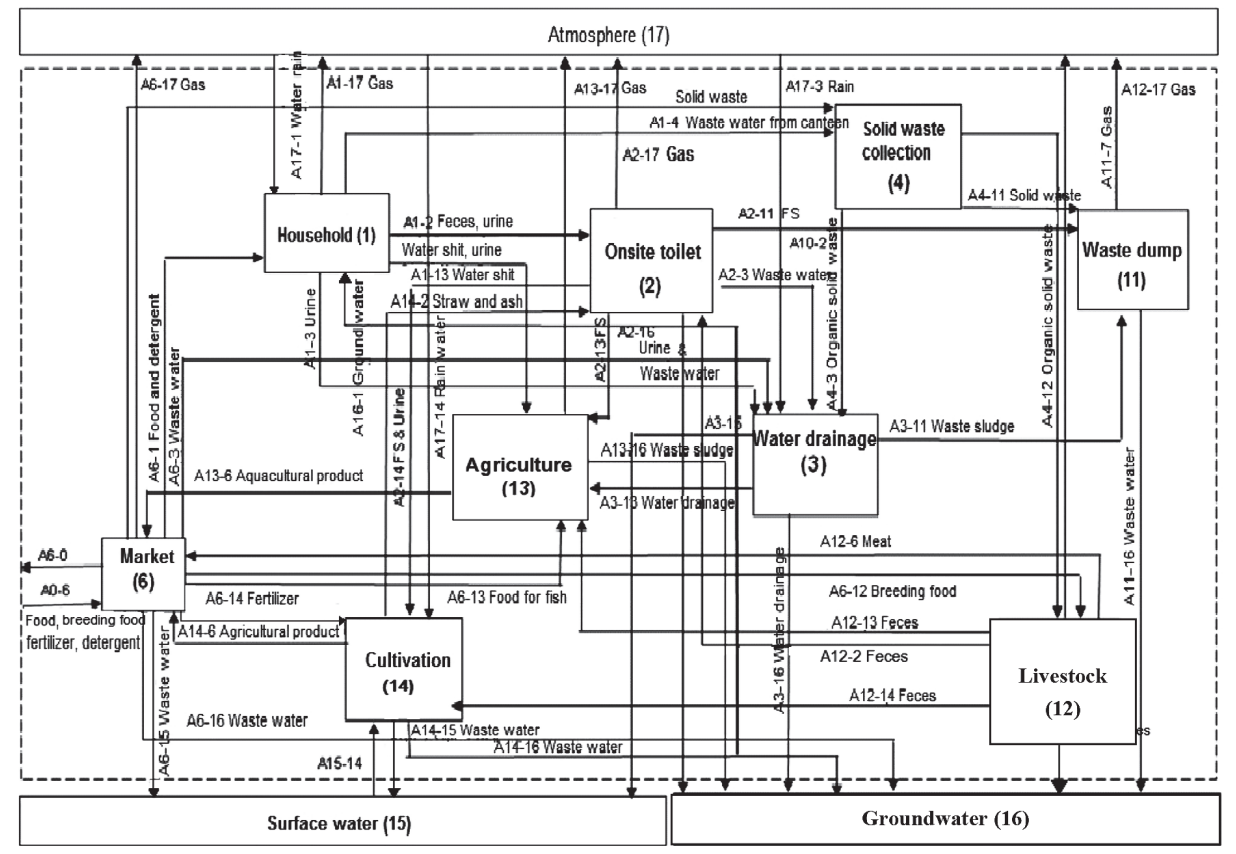

Fig. 6. Material flow analysis (MFA) model of nitrogen transformation in Hai Duong province after the second survey.

the number of parameters should be minimized and unknown parameters simplified or removed from computations.

In practice, three main sources that contribute nitrogen to surface water are cultivation, aquaculture, and water drainage. The measured data in 2012 at the two outlets were used to evaluate model accuracy. Finally, using the defined parameters and input data, the nitrogen loads to the air, surface water, and groundwater in Hai Duong province were estimated for a scenario in 2020.

\section{RESULTS AND DISCUSSION}

Based on the preliminary MFA system and the second survey, the MFA was created (Fig. 4). There are some modifications described in Table 1 including:

- The nitrogen load from the household water supply process was excluded, as the concentration of total nitrogen in drinking water is very small and its exclusion simplified MFA computation.

- The nitrogen load from the production process was also excluded as data collection showed that the annual total nitrogen load from industry in Hai Duong province is about 30 tons per year, compared to 3122 tons per year from paddy fields.

\section{MFA model parameters}

Households

This process includes all activities related to the nitrogen load from households such as cooking, eating, toileting, bathing, and washing. The main pollutant loads (nitrogen and protein) come from food, detergents, cosmetics, urea, and fertilizers. The flow of nitrogen in fertilizer was determined by the amount of protein in the household food supply, since protein is contained in cosmetics and fertilizers. In recent studies, blackwater was found to be discharged into the drainage or aquaculture systems, or a septic tank.

Two sources transmitting nitrogen into households are food and detergents, and water supply to households (Fig. 7). The total loads are 4124 and 362.5 tons per year respectively. Nitrogen in the water supply comes from both ground and rain water. Nitrogen flows discharged through waste water from the kitchen, and feces and urine are 507 and 3793 tons per year respectively. Therefore, nitrogen sources into households are mainly from food and detergents, and nitrogen load to the environment is primarily through feces and urine.

Nitrogen load in this process was determined by the balance between input and output as described in Equation 1. Thus, in 2012, the nitrogen load in this process was 23.8 tons per year ( $0.5 \%$ of total nitrogen input).

\section{On-site sanitation}

The main sources of nitrogen emissions of this process include farm manure discharge into biogas tanks

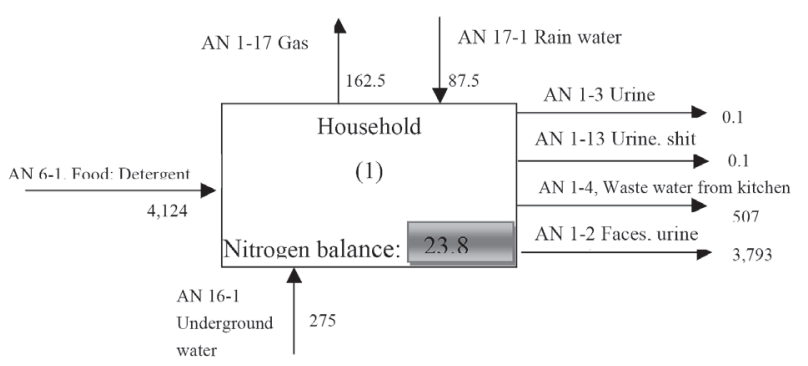

Fig. 7. Nitrogen transformation (tons per year) in the household process. 


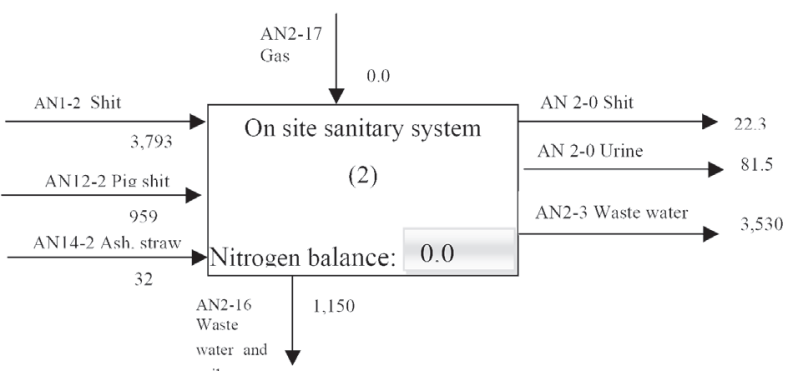

Fig. 8. Nitrogen transformation (tons per year) in on-site sanitation systems.

and human feces and urine, and black water from households, amounting to 959 and 3793 tons per year respectively (Fig. 8). Total nitrogen load in waste water discharged into the sewer system is 3530 tons per year.

\section{Drainage systems}

The major source of nitrogen in this process comes from on-site sanitation systems with a total load of 3530 tons per year (Fig. 9). This source, which discharges into aquaculture ponds or river systems throughout the water drainage system, is 2096 tons per year.

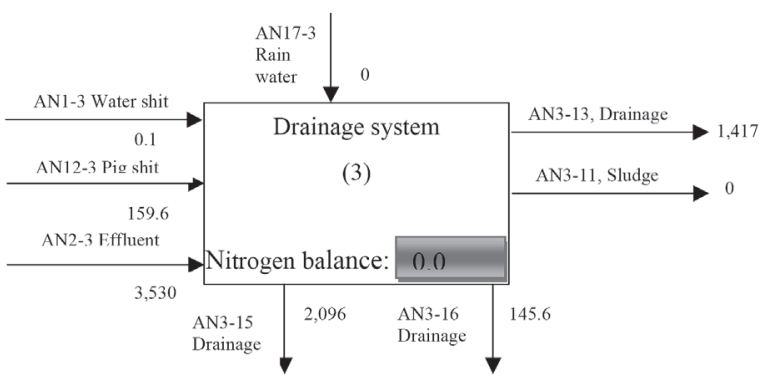

Fig. 9. Nitrogen transformation (tons per year) in drainage systems.

\section{Solid waste collection and treatment}

This process includes the collection of solid waste and the organic food system. The amount of solid waste corresponds to the total amount of organic waste from household waste and market processes.

The main nitrogen source of solid waste collection is from solid waste at the market (9137 tons per year; Fig. 10). Nearly $80 \%$ of nitrogen in solid waste dumped is found at the market waste dump (7716 tons per year). The organic portion of solid waste goes into the livestock process (1049 tons per year). The total nitrogen in this process is 879 tons per year.

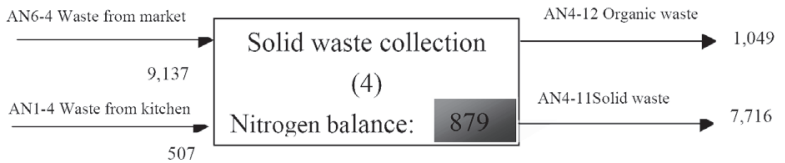

Fig. 10. Nitrogen transformation (tons per year) in solid waste collection and treatment.

\section{Market process}

This process takes place in the market or where goods are exchanged or produced (animals, fish, agricultural production) and then exported out of the study area, and includes goods imported and distributed to local households and agricultural processes (food, detergents, fertilizer, and processed foods for humans and livestock).

Annually, 22634 and 37923 tons of nitrogen is released from food processing for animals and fertilizers respectively (Fig. 11). Nitrogen input is greater than output, by about 60026 tons per year. Thus the nitrogen load in the market process exists both inside and outside the study area. Another reason for a negative exchange rate is due to a lack of information on inputs on the total amount of food, goods and other contributions in the study area.

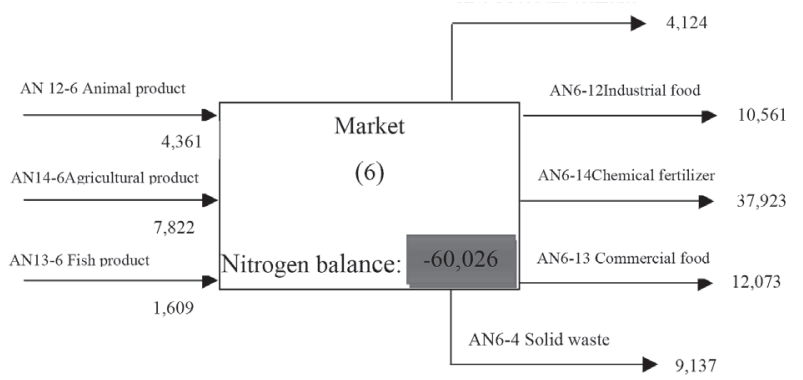

Fig. 11. Nitrogen transformation (tons per year) in the market process.

\section{Waste dump process}

Waste dumping is mainly from solid waste collection and the sewage disposal system. Currently, 7715 tons per year are released into the waste dump as solid waste from solid waste collection. The rate of conversion is very high, since solid waste is not treated in waste dump sites (Fig. 12).

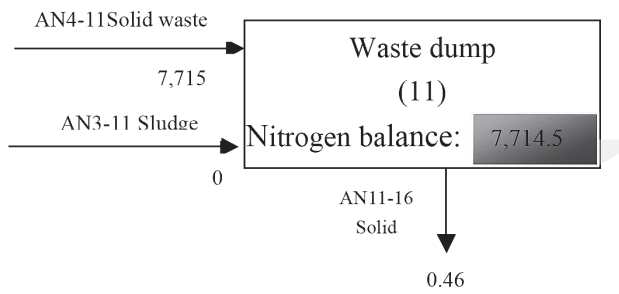

Fig. 12. Nitrogen transformation (tons per year) in the waste dump processs.

\section{Livestock process}

Three main types of livestock were considered: pigs, cattle and poultry. Nitrogen loads are from processed food, agricultural waste, fodder, and food scraps.

Currently, the nitrogen loads to livestock by processed food is 10514 tons per year, and by food waste from households and fodder agricultural waste is 6009 tons per year. The main source of nitrogen emissions in 
this process is 7607 tons per year, elucidated from field assessments. Pigs store only a quarter of the total nitrogen contained in pig feed, with an initial volume of 4322 tons per year. The exchange rate is -1555 tons per year (Fig. 13). This negative exchange rate is due to the nitrogen load in the livestock process existing both inside and outside the study area. Also, information on the total amount of feed for pigs in the study area is lacking.

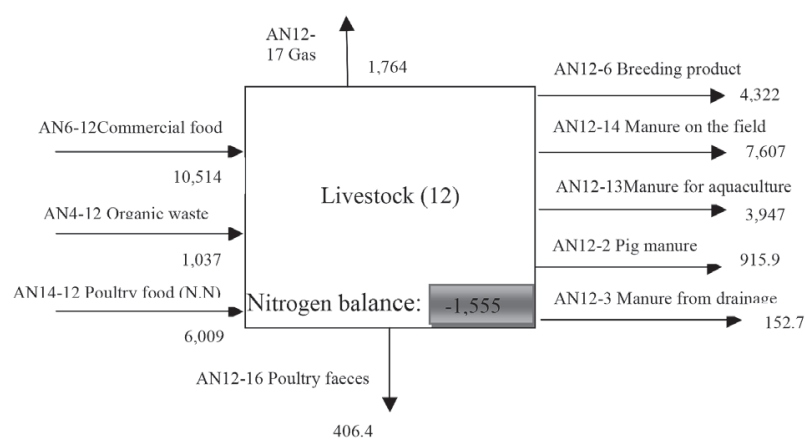

Fig. 13. Nitrogen transformation (tons per year) in the livestock process.

\section{Aquaculture process}

This process describes nitrogen exchanges in fish farming, including the nitrogen load from processed food, fertilizer, and agricultural waste, as well as in water and air. Nitrogen outputs are fish and mud dredged from aquarium lakes (Fig. 14).

Processed fish food is the main nitrogen source in the aquaculture process. Two thirds of total nitrogen is from processed foods (8462 tons per year). Each year, nitrogen accumulated in sludge and water amounts to 1379 and 1829 tons respectively. Therefore, the nitrogen loads into water sources are relatively high in comparison with other processes.

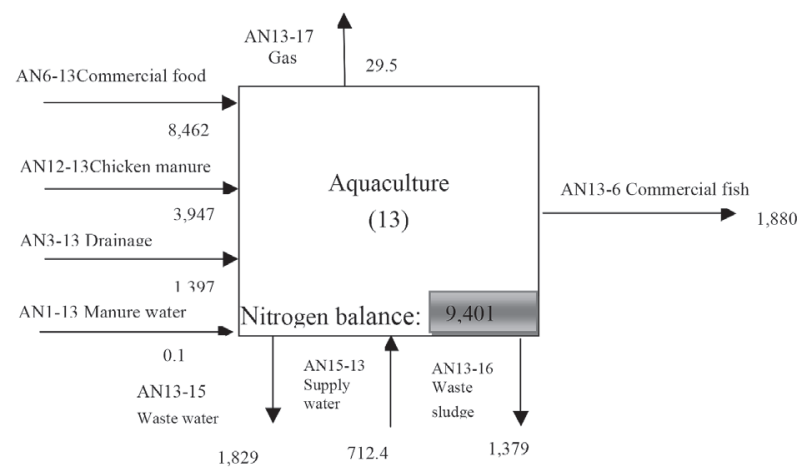

Fig. 14. Nitrogen transformation (tons per year) in the aquaculture process.

\section{Cultivation process (14)}

There are two main rice crops in the study area. Farmers use mainly chemical fertilizers and manure during the growth of rice. Irrigation water is supplied through the Bac Hung Hai canal system. Rice is sold at the market and the agricultural waste or straw is used as animal feed.

The nitrogen sources of the cultivation process are chemical fertilizers and manure (Fig. 15). Air contains $\mathrm{NO}_{\mathrm{x}}$ and $\mathrm{N}_{2} \mathrm{O}$ from the combustion of straw as well as nitrogen evaporation and drainage water discharge from paddy fields during the rainy season. Currently, 37923 tons of nitrogen from chemical fertilizer is applied to paddy fields annually. The nitrogen evaporated into air and surface water is 21995 and 3034 tons per year respectively. Therefore, this represents a source of surface water pollution that requires mitigation.

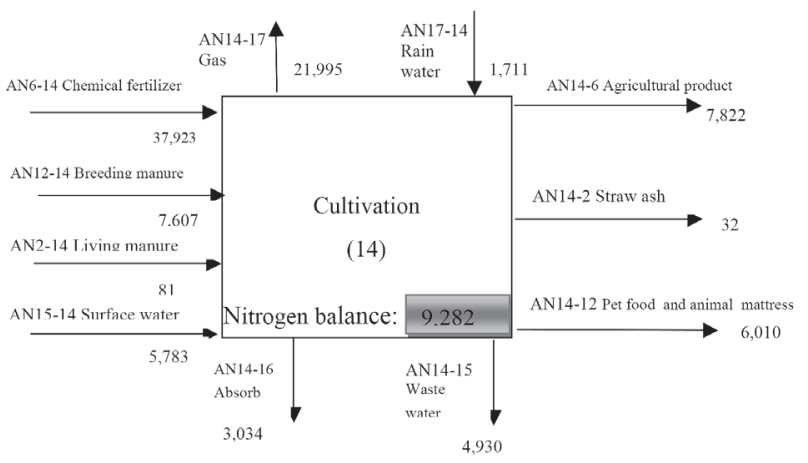

Fig. 15. Nitrogen transformation (tons per year) in the cultivation process.

The law of conservation of matter applies for each substance in each process. The balance of input and output flows (including stock changes) should be zero. Failure to balance these flows can indicate missing flows; this source of error can be eliminated when establishing the balance at the level of goods. Balance differences between input and output of $10 \%$ are common and do not significantly impact conclusions drawn (Brunner and Rechberger, 2004).

Since statistical data in the study area are lacking, the transfer coefficient in the chemical process for the MFA model was determined by trial and error. The model considered many processes; therefore the choice of transfer coefficients was informed by the results of previous studies. For instance, Do et al. (2014) successfully applied the MFA model in order to determine nitrogen load in Nhue-Day river basin using appropriate standards and statistical data. By using the mass balance equations, and trial and error, the MFA model parameters in our study area were determined and the output transformation of nitrogen to surface, groundwater and air was then determined.

\section{MFA of nitrogen transformation for Hai Duong province}

Based on the above results, the MFA was created (Fig. 16). It describes nitrogen loads $\geq 1000$ tons per year (loads smaller than this were excluded from the MFA).

The simulated result of total nitrogen transformed 


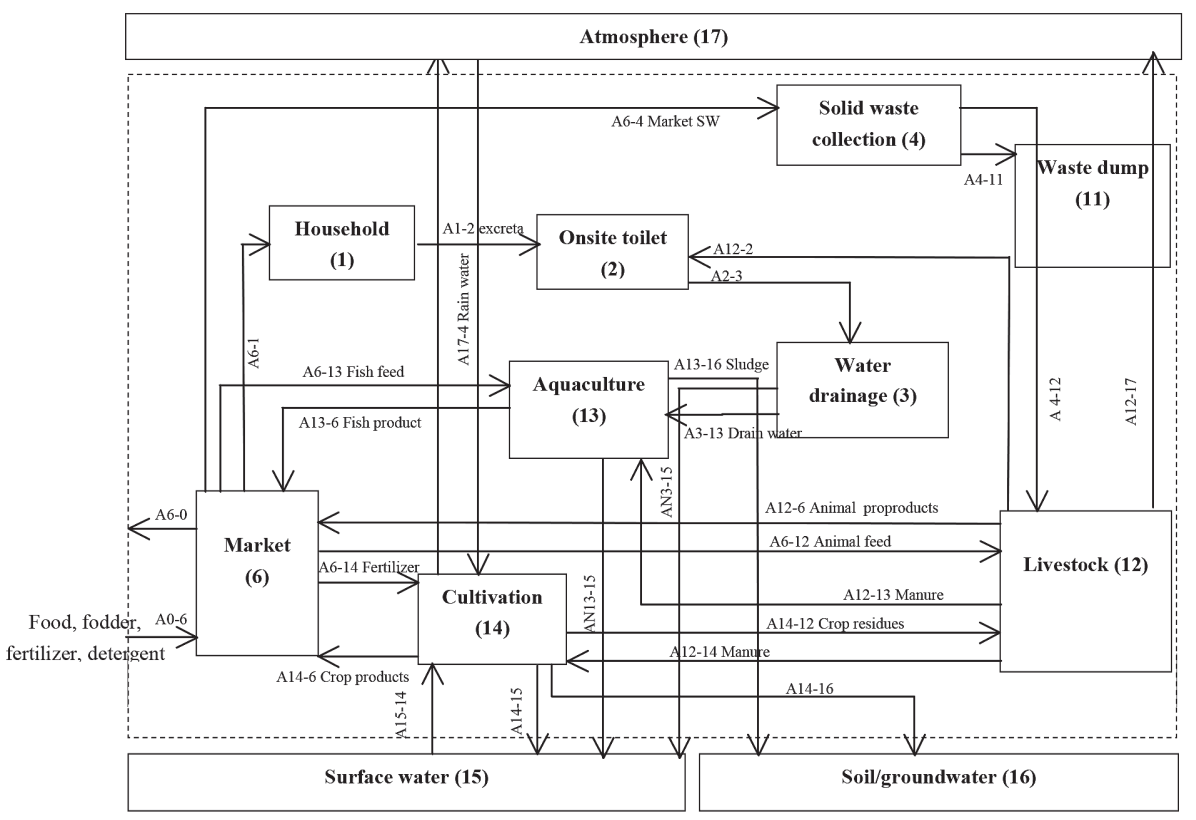

Fig. 16. Material flow analysis (MFA) model of nitrogen transformation in Hai Duong province.

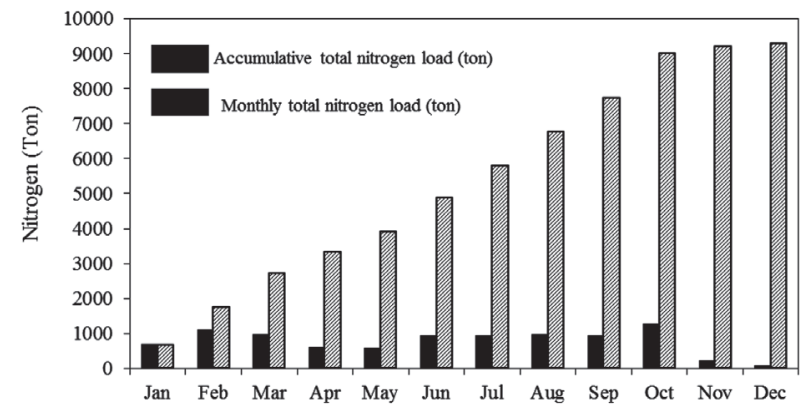

Fig. 17. Total nitrogen transformation into surface water at two outlets (Nos. 1 and 2).

into surface water at the two outlets in 2012 is similar to the measured data. The accumulative total nitrogen load, computed from monthly discharge and nitrogen concentration, was 9271 tons (Fig. 17), whereas simulated total nitrogen was 8855 tons (Table 3). The relative error between simulated and measured nitrogen is $4.7 \%$, indicating that the MFA model is applicable for Hai Duong province. Since some processes were excluded from the model, simulated total nitrogen in the surface water is less than that measured.

The simulated results indicate that nitrogen loads to the air accounted for $64.2 \%$ of total nitrogen, whereas nitrogen loads to surface water and soil or groundwater were $23.9 \%$ and $11.9 \%$ respectively (Fig. 18). Thus it can be concluded that if chemical fertilizer, which contains mainly nitrogen (urea), is applied to crops then greenhouse gas emissions will increase. Therefore, it is recommended that slow-release fertilizer, such as a mixture of nitrogen, phosphorus, and potassium, be used in order to reduce greenhouse gas emissions.

Nitrogen loads to surface water were mainly contributed from paddy fields (55.6\%), aquaculture (20.7\%) and waste water (drainage, 23.7\%; Fig. 19).

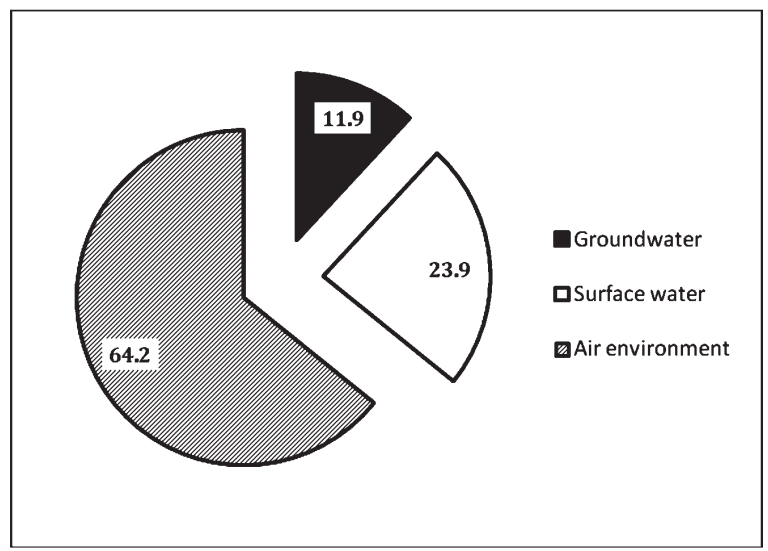

Fig. 18. Total nitrogen transformation into the environment.

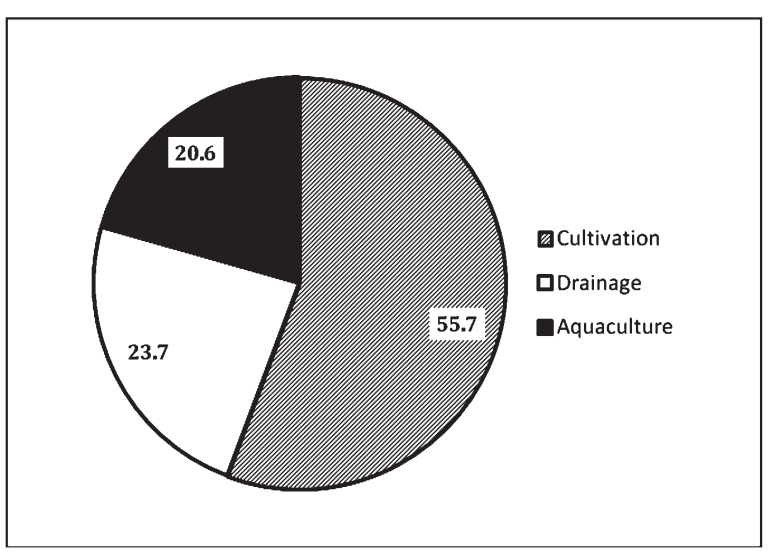

Fig. 19. TTotal nitrogen transformation into surface water. 
Estimation of nitrogen loads in Hai Duong province for scenario in $\mathbf{2 0 2 0}$

Based on the development plan for 2020 (Decision of Hai Duong People's Committee, 2013), socio-eco- nomic and land uses are described in Table 2. There is a big difference between paddy area in 2012 and 2020, since the development plan proposes to decrease the paddy area and increase the residential area. Therefore,

Table 2. Development plan for socio-economic and land use in 2020

\begin{tabular}{|c|c|c|c|c|c|c|}
\hline \multirow{2}{*}{ TT } & \multirow{2}{*}{ Content } & \multirow{2}{*}{ Unit } & \multicolumn{2}{|c|}{ Amount } & \multirow{2}{*}{$\begin{array}{l}\text { Increase/ } \\
\text { Decrease }\end{array}$} & \multirow{2}{*}{$\%$} \\
\hline & & & 2012 & 2020 & & \\
\hline 1 & Population & People & $1,738,480$ & $1,810,000$ & Increase & 4.1 \\
\hline 2 & Paddy area & ha & 63,205 & 58,000 & Decrease & 8.2 \\
\hline 3 & Rice production & Ton & 782,235 & 700,000 & Decrease & 10.5 \\
\hline 4 & Pork production & Ton & 83,572 & 170,000 & Increase & 103.4 \\
\hline 5 & Poultry production & Ton & 26,285 & 37,000 & Increase & 40.8 \\
\hline 6 & Aquaculture production & Ton & 62,684 & 7,5570 & Increase & 20.6 \\
\hline
\end{tabular}

Table 3. Comparison of nitrogen transformation into surface water in 2012 and 2020

\begin{tabular}{|c|c|c|c|c|c|}
\hline \multirow{2}{*}{ No. } & \multirow{2}{*}{ Process } & \multicolumn{2}{|c|}{$\mathrm{N}$ load (ton/year) } & \multirow{2}{*}{$\begin{array}{l}\text { Increase/ } \\
\text { Decrease }\end{array}$} & \multirow{2}{*}{$\%$} \\
\hline & & 2012 & 2020 & & \\
\hline 1 & Aquaculture & 1,829 & 2,696 & Increase & 47.4 \\
\hline 2 & Cultivation & 4,930 & 4,524 & Decrease & 8.2 \\
\hline 3 & Drainage & 2,096 & 2,809 & Increase & 34 \\
\hline & Total & 8,855 & 10,029 & Increase & 13.3 \\
\hline
\end{tabular}

Table 4. Comparison of nitrogen transformation into air in 2012 and 2020

\begin{tabular}{|c|c|c|c|c|c|}
\hline \multirow{2}{*}{ No. } & \multirow{2}{*}{ Process } & \multicolumn{2}{|c|}{ N load (ton/year) } & \multirow{2}{*}{$\begin{array}{l}\text { Increase/ } \\
\text { Decrease }\end{array}$} & \multirow{2}{*}{$\%$} \\
\hline & & 2012 & 2020 & & \\
\hline 1 & Cultivation & 21,995 & 20,184 & Decrease & 8.2 \\
\hline 2 & Livestock & 1,764 & 1,764 & - & 0 \\
\hline & Total & 23,759 & 21,948 & Decrease & 7.6 \\
\hline
\end{tabular}

Table 5. Comparison of nitrogen transformation into groundwater in 2012 and 2020

\begin{tabular}{|c|c|c|c|c|c|}
\hline \multirow{2}{*}{ No. } & \multirow{2}{*}{ Process } & \multicolumn{2}{|c|}{ N load (ton/year) } & \multirow{2}{*}{$\begin{array}{l}\text { Increase/ } \\
\text { Decrease }\end{array}$} & \multirow{2}{*}{$\%$} \\
\hline & & 2012 & 2020 & & \\
\hline 1 & Cultivation & 3,034 & 2,784 & Decrease & 8.2 \\
\hline 2 & Livestock & 1,380 & 1,957 & Increase & 41.8 \\
\hline & Total & 4,414 & 4,741 & Increase & 7.4 \\
\hline
\end{tabular}

Table 6. Comparison of total nitrogen transformation into surface water, air, and groundwater in 2012 and 2020

\begin{tabular}{|c|c|c|c|c|c|}
\hline \multirow{2}{*}{ No. } & \multirow{2}{*}{ Process } & \multicolumn{2}{|c|}{ N load (ton/year) } & \multirow{2}{*}{$\begin{array}{l}\text { Increase/ } \\
\text { Decrease }\end{array}$} & \multirow{2}{*}{$\%$} \\
\hline & & 2012 & 2020 & & \\
\hline 1 & Surface water & 8,855 & 10,029 & Increase & 11.7 \\
\hline 2 & Air & 23,759 & 21,948 & Decrease & 7.6 \\
\hline 3 & Groundwater & 4414 & 4,741 & Increase & 7.4 \\
\hline & Total & 37,028 & 36,718 & Decrease & 0.8 \\
\hline
\end{tabular}


total nitrogen application in paddies will also decrease, resulting in a decrease in the contribution of nitrogen transformation from cultivation into surface water and air.

\section{Application of MFA to scenario in 2020}

Using the defined parameters and above input data, the nitrogen loads in Hai Duong province for a scenario in 2020 were calculated and are compared with those of 2012 in Tables 3, 4, 5, and 6.

Total nitrogen loads from all main sources in 2020 will decrease $0.8 \%$ or 310 tons per year in comparison with 2012 (Table 6).

\section{CONCLUSIONS}

This paper presents an MFA model that provides an overview of existing nitrogen flows and identifies weaknesses in nutrient management in Hai Duong province, Cau River Basin, Vietnam. First, the dynamic transport and transformation of nitrogen were quantified using results from surveys and previous studies. All nitrogen inputs including agriculture, aquaculture, and domestic sources, as well as nitrogen outputs including to the atmosphere, surface water, and soil or groundwater were considered and simulated by mass balance and network equations. The rate of nitrogen transformation in each process and parameters of the MFA model were then determined and verified by measured data. The MFA model results indicate that nitrogen loads to the air accounted for $64.2 \%$ of total nitrogen whereas nitrogen loads to surface water, and soil or groundwater accounted for $23.9 \%$ and $11.9 \%$ respectively. Moreover, results show that nitrogen loads from paddy fields were the main contributors to surface water (55.6\%). Other contributions to surface water were from aquaculture (20.7\%) and waste water (23.7\%). Finally, the nitrogen loads in Hai Duong province were estimated for a scenario in 2020 using the defined parameters and input data. These results show that nitrogen loads from paddy fields are the primary contributors to surface water and are the main cause of nitrification of the canals and river system. Therefore, it is recommended that slow-release fertilizers, such as a mixture of nitrogen, phosphorus, and potassium, be applied for paddy cultivation in order to reduce the pollutant load to the environment caused by nitrogen release. The MFA model is applicable to the study area and provides a useful tool to support managers and authorities in assessing and adjusting the local planning of Hai Duong province in the context of considering the relationship between economic development and environmental protection of the Cau River Basin in general.

\section{ACKNOWLEDGEMENTS}

This research was funded by the Vietnam National Foundation for Sciences and Technology Development (NAFOSTED) under grant number 105.08-2013.02.

\section{REFERENCES}

Belevi, H., C. Leitzinger, C. Binder, A. Montangero, M. Strauss and C. Zurbrügg, 2000 Material Flow Analysis: A Planning Tool for Organic Waste Management in Kumasi, Ghana. EAWAG/SANDEC, ETH Zurich, (Switzerland)

Brunner, P, H and H. Rechberger 2004 Practical handbook of material flow analysis. Int. J. Life Cycle Assess., 9: 337-338

Chinh. L.V., T. T. Lan, N. M. Ha and V. T. H. Nghia 2015a Simulation of Flow Runoff in Cau River Basin by Using GIS Base Distributed Parameter Model, National Annual Conference on Water Resources, Hanoi Water Resources University

Chinh L.V., L. P. Dong, T. T. Thao, N. T. L. Huong and N. T. Cuu 2015b Study on Simulation and Prediction of Nitrogen Runoff in Cau River Basin by Using GIS Base Distributed Parameter Model, Journal of Sciene and Technology, University of Science, Vietnam National University, 31: 13-21

Decision of Hai Duong People's Committee 2013. Development Plan of Hai Duong Province up to 2020 and vision 2030 Decision No. 3155/QĐ-UBND dated November $15^{\text {th }} 2011$

Do, N. T., D. A. Trinh and K. Nishida 2014 Modification of uncertainty analysis in adapted material flow analysis: Case study of nitrogen flows in the Day-Nhue River Basin, Vietnam. Resour. Conserv. Recy., 88: 67-75

Japan Environment Agency 1992 Quality of the environment in Japan 1992, Tokyo: Japan Environment Association

Montangero, A., T. K. T. Nguyen and H. Belevi 2004 Material flow analysis as a tool for environmental sanitation planning in Viet Tri, Vietnam, 30th WEDC International Conference, Vientiane: Lao PDR

Montangero, A. 2006 Material flow analysis for environmental sanitation planning in developing countries: An approach to assess material flows with limited data availability

Montangero, A. and H. Belevi 2007 Phosphorus Flow Model for Hanoi: A Tool for Evaluating Environmental Sanitation Options, EAWAG, Swiss Federal Institute of Aquatic Science and Technology, Switzerland, University of Innsbruck, Institute of Environmental Engineering, Innsbruck: Austria

Sinsupan, T. 2004 Material flux analysis (MFA) for planning of domestic wastes and wastewater management: Case study in Pak Kret Municipality, Nonthaburi, Thailand. AIT Master Thesis, School of Environment, Resources and Development. Asian Institute of Technology, Bangkok: Thailand

Steurer, A. 1992. Stoffstrombilanz Osterreich 1988. [Material flow balance for Austria 1988.] Social Ecology Working Paper 26. IFF Social Ecology, Vienna: Austria 